Journal Of Agriculture and Social Research (JASR) Vol. 8, No.1, 2008

\title{
APPRAISAL OF INDIGENOUS PIG PROCUTION AND MANAGEMENT PRACTICES IN RIVERS STATE, NIGERIA
}

\section{IRONKWE M.O. AND K. U. AMEFULE}

\begin{abstract}
The study was conducted to obtained baseline data on pig production and management practices in Rivers State. The study used structural questionnaire administered to 300 household pig farmers, randomly selected from five communities in two Local Government Areas (LGAs) of Rivers State Nigeria. Data generated included socio-economic characteristics of respondents and pig production Parameters. The data collected were analysed by descriptive statistics such as means standard deviation and percentages. The result showed that the influence of some socio-economic variable on pig production. Over $85 \%$ of the respondents acquired their foundation stock from the open markets while some got from neighbours' herds. Grains, agro-industrial and household wastes were the major sources of animal feed. There was a very low awareness level for the use of commercial feeds. Survey results indicated that the main disease problems reported by the respondents were helminthiasis, cough, diarrhoea, skin disease mainly sarcoptic mange and lice infestation. The number of weaned piglet/sow/year was highest for intensive followed by semiintensive and extensive having the least number of piglets per year. The pig producers were confronted with major production constraints such as disease incidence, high cost of feeds, high cost of conventional drugs and poor housing. The need for and means of improving pig production were highlighted.
\end{abstract}

Key words: indigenous pig production, management systems, disease profile, pig production constraints.

\section{INTRODUCTION}

The growing population in Nigeria has greatly influenced the demand for animal protein over the years and this has caused the supply of meat to be in low demand. The intake of animal protein in Nigeria stands at $3.5 \mathrm{~g} / \mathrm{caput} / \mathrm{day}$. This is still far less than the $35 \mathrm{~g}$ caput/day as recommended by Word Health Organization (WHO). This shortage of animal protein consumption is partly due to the high cost of conventional sources of meat like cattle, Pig, Goat, Sheep and poultry, (Tewe, 1999). It is therefore necessary to search for a cheaper alternative source of meat to meet the ever increasing demand for animal protein. This quest can only be met by "Short - cycled" animals such as rabbits, poultry and pigs. Pigs have been described as one of the most prolific and fast growing livestock that can convert food waste to valuable products. They excel above other red meat animals such as cattle, sheep and goat in converting feed to flesh. And their annual growth rate $(3.8 \%)$ is higher than that of the human population $(2.30-2.80 \%)$. The indigenous pigs have been recommended as a good alternative source of cheap, high quality animal protein that suits escalating human population. They have relatively low cost of production and their growth rate is fast, (Osaro, 1995). They also have short generation interval, high production potential, high prolificacy and high carcass yield. They adapt easily to environmental conditions (ILCA, 1992). Pig Production has therefore been advocated as a short term measure towards alleviating the animal protein and calorie deficit, especially where there are no religious edicts preventing their production and consumption, (Eusebio, 1984). Nigeria is estimated to have 4.4million pigs, about $78 \%$ of these are found in the sub-humid zones of Northern and southern Guinea savannah (Shaib et al, 1997). Most of the pigs are reared in the extensive system, and their productivity has been reported to be low (Okorie, 1978). Efforts have been directed therefore towards improving their productivity through adequate nutrition (Ladokun et al; 2006), improved health and management )Balogun 1981), breed 
development specifically through cross - breeding with superior exotic breeds. The pig is not only a source of animal protein, it also serves as an investment alternative and source of additional income especially in the rural areas. In the southern part of Nigeria, pig farming is kept in commercial quantities because there are no ethnic or religious taboos forbidding its production. But most times, pig keeping has been reported to be a secondary enterprise and represents some proportion for the income earned by households, most especially women. (Holness, 1991).

Improvement in quantity as well as well as quality of pig herds will go a long way in meeting the nutritional requirement of Nigerians and it will also cut down drastically on the colossal bill, resulting from the importation of animals and animal products. Such improvement will bridge the gap between animal protein production and consumption with an attendant advantage of increased rural employment and income. In the light of the above observation, there is the need for farmers and government agencies such as National Directorate for Employment (NDE), Agricultural Development Projects (ADP) located where there is no religious ethics against the production and consumption of pigs, to give pig production a top priority in their programmes of activities. The aim of the study therefore was to appraise the general production level of pigs management and the constraints against its rapid expansion in the study areas.

\section{MATERIALS AND METHODS}

The study area is Rivers State, Nigeria.The state ranks sixth in pig production in Nigeria representing $60 \%$ of the total pig production in Nigeria (State Ministry of Agriculture, Livestock Unit 2006). Rivers State is situated in the South - South vegetation zone. Rainfall lasts from march - November with dry period from December to March. The study was conducted in four communities in two Local Government Areas (L.G.As). The soil is rich and suitable for the cultivation of wide range of crops. Most of the ethnic groups are farmers that keep a good number of pigs, small ruminants and poultry in addition to cropping. Rivers State is a humid region and is predominantly a Christian dominated area where pig production and consumption is not prohibited. The location was purposively chosen for the study because majority of the farmers in the study areas are involved in pig production. The areas are also a known potential pig markets in the state. Ikwerre and Etche Local Government Areas were also chosen because of large number of pig farmers in the area.

A total of 300 households involved in pig farming were selected from the two Local Government Areas. One hundred and fifty (150) households were randomly selected from each LGA. Within each LGA, five communities were selected and thirty households interviewed in each of them. The study was conducted between June 2006 and May 2007 in order to cover both the dry and wet seasons. Variable investigated included pig distribution by households, management practices, sources of feed by season, preferred feedstuff, livestock disease profile and constraints to pig production. Descriptive statistics such as percentages, means scores and frequency tables were used in the analysis of the data generated.

\section{RESULTS AND DISCUSSION \\ Demographic characteristics of pig farmers}

Results in Table 1 shows that the lowest age group $(21$ - 30 years $)$ had the largest pig herd size. Another group within $(31$ - 40 years) had the second largest group of herd size. This trend continued and declined as the ages of the pig farmers increased. Above (60 years old had the lowest number of herd size. Majority of the respondents were within the younger age groups in agreement with earlier findings. Household size includes members from the age of seven years in a family that were engaged in production activities. Table 1 also shows that $37 \%$ of the respondents fell with the range of $1-5$ members per household while 40,15 and $8 \%$ fell within the rangers of $6-10,11-$ 15and $16-20$ members respectively. Family labour was a major source of labour in this study. The 
majority of the respondents (52\%) had less than four adult pigs while $29 \%$ had between 4 and 6

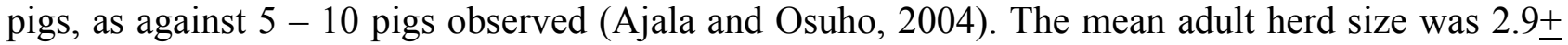
1.6. All the respondents were small scale farmers. This conforms to an earlier report by (Pathiraja et al 1986), that farming in Southern North Savannah region is primarily a small holder business.

Table 1: Demographic characteristics of pig farmers $(n=300)$

\begin{tabular}{lll} 
Demographic characteristics & Frequency & Percentage \\
\hline Age & 87 & 29.0 \\
$21-30$ & 79 & 26.3 \\
$31-40$ & 60 & 20.0 \\
$41-50$ & 45 & 15.7 \\
$51-60$ & 29 & 15.7 \\
Above 60 & & \\
Household size & 111 & 37 \\
$1-5$ & 120 & 40 \\
$6-10$ & 45 & 15 \\
$11-15$ & 24 & 8 \\
$16-20$ & & \\
Herd size & 156 & 52.0 \\
$1-3$ & 87 & 29.0 \\
$4-6$ & 57 & 19.0 \\
$7-9$ & $2006-2007$ & \\
\hline
\end{tabular}

Source: Field survey $2006-2007$

Table 2 shows that about $85 \%$ of the respondents acquired their foundation stock from the open market, while others got theirs from neighbours' herds, in contrast to some elite pig farmers that acquired from Shell Petroleum Company, private piggery farms in Yenagoa and Amasoma. It was generally observed that the best breeding stock rarely goes to the market, resulting in the use of foundation stock with poor breeding qualities. The result also indicated non- utilization of improved breeds from government farms due to unavailability of such, increased use of own stock and that of neighbours, which give rise to inbreeding and consequently low productivity. (Olomu et al; 1995), most herds however did not keep breeding boars for breeding. Cash payment are often made for this service or a promise of one piglet after farrow is made. Household wastes and local brewers' residue (from rice) were the major sources of animal feed (Table 3). However, Adeshinwa et al (2004) reported that brewers wasters is a source of feed ingredient and not a complete feed. Most respondents practice the semi intensive system of management, whereby animals are partially confined especially during the dry season and totally during the wet season. Harvested grasses are fed along with household wastes such as peels of yams, potatoes, coco yam, boiled cassava, brans and cereal grains like maize, etc. only $10 \%$ of the respondents indicated having used any form of commercial feed. 
Table 2: Sources of parent stock

$\begin{array}{lll}\text { Source } & \text { Frequency } & \text { Percentage } \\ \text { Market } & 254 & 84.0 \\ \text { Inherited } & 20 & 6.7 \\ \text { Neighbour } & 96 & 32.0 \\ \text { Bred } & 76 & 26.0 \\ \text { Government farm } & 9 & 3.0 \\ \text { Borrowed } & 25 & 8.3 \\ \text { Others } & 10 & 3.3\end{array}$

*Multiple responses

Source: field survey 2006 - 2007.

The management systems used closely determined the source of feed. Some practiced the extensive system while very few respondents practice the intensive system of management and the remaining $10 \%$ respondents practiced the intensive system of management. Rekwot et al; (1990), noted that under the intensive system, pigs are under better conditions like good nutrition and management. Pigs under semi-intensive system perform better than the extensive system, because apart from the fact that they scavenge freely during the day, they are supplement by their owners. Hence, they tend to have better nutrition and body conditions than pigs under the extensive system. Tegbe et al; (1996). Pig production in the study area is bedeviled by so many problems, ranging from diseases, unavailability of improved stocks, to high cost of pigs and scarcity of nutritionally adequate feeds capable of supporting good pig growth.

The majority of the respondents provided some form of housing to pigs. Various types of housing materials were used by the respondents depending on their scale of production (size of their herd). Two types of pig houses identified in the study area were the cement: block walls with zinc roof and concrete floor type, and the mud-brick walls with thatched roof, and rammed earth floor type. The low cost pig houses were built mainly from locally available materials. Most of the respondents used mud-brick walls with thatched roof type of housing, while some of them used the cement block wall with zinc roof. Apart from lack of durability of the building of the building, it predisposes the pigs to diseases. The cement block walls with zinc roof and concrete floor has been advocated because of its durability and high level of hygiene.

Table 3: source of animal feed by season

\begin{tabular}{|c|c|c|c|c|}
\hline \multirow[t]{2}{*}{ Source } & \multicolumn{2}{|l|}{ Dry season } & \multicolumn{2}{|l|}{ Wet season } \\
\hline & Frequency & Percentage & Frequency & Percentage \\
\hline House hold waste & 238 & 79.3 & 204 & 68.0 \\
\hline $\begin{array}{l}\text { Brewer' residue (rice and } \\
\text { wheat wastes) }\end{array}$ & 204 & 68.0 & 186 & 62.0 \\
\hline Cut grasses & 42 & 14.0 & 51 & 17.0 \\
\hline Commercial feeds & 30 & 10.0 & 30 & 10.0 \\
\hline Animal fend for self & 156 & 52.0 & 117 & 39.0 \\
\hline Don't know & 9 & 3.0 & 6 & 2.0 \\
\hline
\end{tabular}

*Multiple responses recorded

Source: Field survey 2006 - 2007

Survey results indicate that the main disease problems reported by the respondents were helminthiasis, cough, diarrhea, skin disease mainly sarcoptic mange and lice infestation. There was also high incidence of worms (helminthiasis) and diarrhea was more prevalent from July to 
September, corresponding to the peak of the wet season. Helminthiasis, sarcoptic, mange and gastroenteritis were observed to be the commonest diseases in the herd.

\begin{tabular}{|c|c|c|c|c|}
\hline Source & $\begin{array}{l}\text { Dry season } \\
\text { *Frequency }\end{array}$ & $\%$ & $\begin{array}{l}\text { Wet season } \\
\text { *Frequency }\end{array}$ & $\%$ \\
\hline $\begin{array}{l}\text { Diarrhea } \\
\text { (gastroenteritis) }\end{array}$ & 208 & 69.3 & 133 & 44.3 \\
\hline Cough/pneumonia & 71 & 23.7 & 44 & 14.6 \\
\hline Mange/Lice & 195 & 65.0 & 106 & 35.3 \\
\hline \multicolumn{5}{|l|}{ Infestation } \\
\hline Anaemia & 64 & 21.3 & 82 & 27.3 \\
\hline Ascaris suum & 30 & 10.1 & 17 & 5.7 \\
\hline $\begin{array}{l}\text { Worm } \\
\text { (Helminthiasis) }\end{array}$ & 154 & 51.3 & 182 & 60.7 \\
\hline Mastitis & 40 & 13.3 & 31 & 10.3 \\
\hline
\end{tabular}

Mange and lice infestation can cause considerable losses because of the extreme itching and continuous scratching of the affected area, especially when prevalence is high during the dry season, as recorded in Table 4. In several cases, the entire body surface becomes affected. There is loss of appetite and body weight gain is severely depressed. The low incidence observed in the wet season was due to high humidity during the rainy season, which is not conducive to lice development. Although, there was high incidence of diarrhea in the study area, respondents noted that it was more common with young pigs (piglets) and was observed to be probably responsible for their mortalities. Most mortality cases were reported to occur in piglets at the pre-weaning age of three mouths and below

Study areas used iron rich soil and wood ash in combating anaemia (Shortage of iron in the blood) in piglets. Although wood ash will not provide iron, it provides other important minerals such as calcium and phosphorous which are important for bone development of the piglets. For mange, treatment involved the removal of scales brush and smearing with oil. For the control of ecto parasites also hot wood ash and lime were used. Response to diseased attack varied among the respondents. Some of the respondents slaughtered and ate pigs showing signs of disease attack. Observations revealed that during confinement pig are not separated into sex or age. This encouraged inbreeding and early maturity of gilts. In the dry season, however the pigs roam about freely and mate indiscriminately. Gilts come into early maturity due to constant contact with the boars. The presence of the boar stimulates gilts to attain puberty early and hastens onset of estrus of postpartum Sows leading to shortening of farrowing intervals with overall improvement of the reproductive efficiency. Other problems identified were lack of capital for expansion and high cost of transportation.

\section{CONCLUSION}

To boost the indigenous pig performance, there is need to improve management, the intensive system which has the advantage of reducing disease incidence and mortality rates is therefore advocated. Prompt disease control measures will improve overall productivity of pigs. A better housing measure of cement - brick wall with zinc roof and concrete floor-type will also help. Pig production offers farmers among other benefits a readily available income and serves as a sources of high quality animal protein for households in addition to it socio-economic values. Hence, there 


\section{Journal Of Agriculture and Social Research (JASR) Vol. 8, No.1, 2008}

is urgent need to develop and implement intervention programmes that will minimize high mortality rate in the programmes in order to increase the level of production in the study areas.

The resultant effect of higher animal productivity at the farmer's level can be seen in enhanced income and improved living standards of the farmers and their household as well as increased animal protein for Nigerians.

\section{REFERENCES:}

Ajala, M.K and S.A Osuhor (2004). Economic analysis of returns and cost structre in swine production in Kaduna State, Nigeria. Trop Journal Animal Sci, 7 (1): 11 - 18

Adeshinwa, A.O.K and B.K Ogunmodede (2004). Performance and serum metabolites of growing pigs fed diets containing "dusa" and cashew nut testa as protein sources. Indian Journal Animal Sci. 74 (1): 113 - 116

Balogun, T.F. (1981). Swine production in Nigeria. Problems and prospects. The Nigerian Journal of Agric. Extension pp. 32 - 37. Vol. 4 No. 6

Eusebio, J.A. (1984). Pig production in the Tropics. Intermediate Tropical Agriculture series. Zaria, Kaduna State.

Holness, H.D. (1991) The Tropical Agriculturists (pigs), Macmillian/CTA Ltd, London

ILCA, (1992) International Livestock Centre for Africa. Utilization of feed resources in relation to nutrition and physiology. Proceedings of the $25^{\text {th }}$ International Symposium of Tropical Agricultural Research, Tsukoba Japan, September, $24^{\text {th }}-25^{\text {th }}, 92 \mathrm{p}$.

Ladokun, A.O Egbunike, G.N, Adejumo, D.O and O.A. Sokunbi (2006). The effect of three dietary crude protein levels on digestibility and tests function in male pubertal rabbits.

Tropicultura, 24 (1): $3-6$.

Olomu, J.M and S.O. Oboh (1995). Pig production in Nigeria: principles and practice. AJACHEM Publication Nigeria

Osaro, O.M (1995). Enhancing production performance of small holder pig farming. In: Oyedokun A.O and Adeshinwa (Eds) Pig production Workshop Training Manual, N.A.E.R.L.S/A.B.U. Zaria Nigeria pp. $100-130$.

Okorie, J.U (1978) A Guide to livestock production in Nigeria. Macmillian Ltd, London, 155p.

Pathiraja, N. Rekwot, P.I., Oyedipe, E.O, Alhassan, W.S. and P.M Danda (1986). Studies in the Pig production in Nigeria. In: Osinowo, O.A, Taiwo, B.B.A, Njoku P.C., Tegbe, T.S.B and Umaru, M. (eds) Proceedings of $11^{\text {th }}$ Annual Conference, Nigerian Society for Animals Production, A.B.U. Zaria, Nigeria. Pp. 133 - 138.

Rewot, P.I., Otchere, E.O. Ehoche, O.W., Danda, P.M. Tegbe, T.S.B and S.O. Okon (1990). Reproductive performance of pig under traditional system of management in the sub humid zone of Northern Nigeria. Paper presented at the $15^{\text {th }}$ Annual Conference of the Nigeria Society for Animal Production held at Ago-Oloye, Ogun State University from $25^{\text {th }}$ $-29^{\text {th }}$ March 1990. 
Shaibu, B:, Ahiju, A and J.S. Bakshi (1997). Nigerian National Agricultural Research Strategy Plan: 1996 - 2010. Department of Agricultural Sciences. Federal Ministry of Agriculture and Natural Resources, Abuja.

Tewe, O.O (1999). Sustainability and development paradigms from Nigeria livestock industry. Inaugural lecture. Faculty of Agriculture and Forestry, University of Ibadan. 42p.

Tegbe, T.S. B and A.O.K Adeshinwa (1996): General management of pigs in Nigeria. In: (1.1. Dafwang et al. Eds.) Ration Formulation Manual for poultry and pigs using Nonconventional feedstuffs. Publication of NAERLS/ABU, Zaria Pp.. $8-13$. 